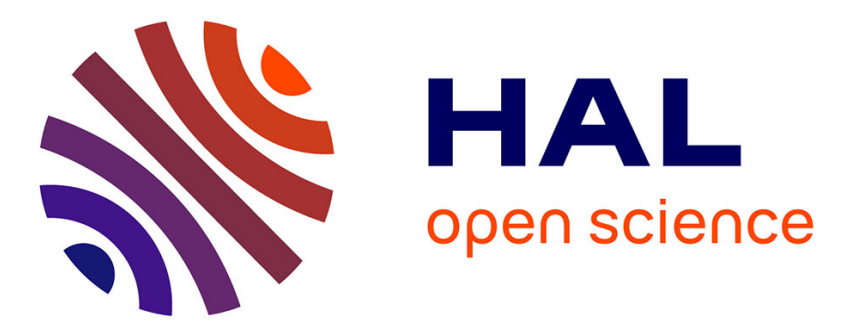

\title{
US strategy for forest management adaptation to climate change: building a framework for decision making
}

\author{
V. Alaric Sample, Jessica E. Halofsky, David L. Peterson
}

\section{To cite this version:}

V. Alaric Sample, Jessica E. Halofsky, David L. Peterson. US strategy for forest management adaptation to climate change: building a framework for decision making. Annals of Forest Science, 2014, 71 (2), pp.125-130. 10.1007/s13595-013-0288-6 . hal-01098403

\section{HAL Id: hal-01098403 https://hal.science/hal-01098403}

Submitted on 24 Dec 2014

HAL is a multi-disciplinary open access archive for the deposit and dissemination of scientific research documents, whether they are published or not. The documents may come from teaching and research institutions in France or abroad, or from public or private research centers.
L'archive ouverte pluridisciplinaire HAL, est destinée au dépôt et à la diffusion de documents scientifiques de niveau recherche, publiés ou non, émanant des établissements d'enseignement et de recherche français ou étrangers, des laboratoires publics ou privés. 


\title{
US strategy for forest management adaptation to climate change: building a framework for decision making
}

\author{
V. Alaric Sample • Jessica E. Halofsky • David L. Peterson \\ Received: 8 October 2012 /Accepted: 3 April 2013 /Published online: 30 April 2013 \\ (C) INRA and Springer-Verlag France 2013
}

\begin{abstract}
- Context Recent policy changes in the USA direct agencies managing federal forests to analyze the potential effects of climate change on forest productivity, water resource protection, wildlife habitat, biodiversity, and other values.

- Aims This paper describes methods developed to (1) assess current risks, vulnerabilities, and gaps in knowledge; (2) engage internal agency resources and external partners in the development of options and solutions; and (3) manage forest resources for resilience, not just in terms of natural ecosystems but in affected human communities as well.

- Methods We describe an approach designed to characterize certain climate change effects on forests, and estimate

Handling Editor: Marc Hanewinkel

Contributions of the co-authors V. Alaric Sample: Wrote the paper to provide synthesis of multiple, related research projects within overarching context of revised US policies regarding adaptation to climate change; presented paper at the conference on Tackling Climate Change: The Contribution of Forest Science, Tours, France, May 21-25, 2012.

Jessica E. Halofsky: Lead scientist for research project on strategies for climate adaptive management of vegetation, wildlife, aquatic resources, hydrology, and transportation systems on Olympic National Forest and Olympic National Park. Reviewer and contributing co-author of paper. David L. Peterson: Lead scientist for research project on responding to climate change in National Forests, and development of a guidebook for developing adaptation options. Reviewer and contributing co-author of paper.
\end{abstract}

Electronic supplementary material The online version of this article (doi:10.1007/s13595-013-0288-6) contains supplementary material, which is available to authorized users.

\section{A. Sample $(\square)$}

Pinchot Institute, 1616 P Street NW, Washington, DC 20036, USA

e-mail: alsample@pinchot.org

\section{J. E. Halofsky}

School of Environmental and Forest Sciences, University of Washington, PO Box 352100, Seattle, WA 98195, USA

e-mail: jhalo@uw.edu

\section{L. Peterson}

USDA Forest Service, Pacific Northwest Research Station, 400 N.

34th Street, Seattle, WA 98103, USA

e-mail: peterson@fs.fed.us the effectiveness of response options ranging from resistance to a realignment of management objectives.

- Results Field testing on a $6,300 \mathrm{~km}^{2}$ area of conifer forest in the northwestern USA shows this decision model to be useful and cost-effective in identifying the highest sensitivities relating to vegetation management, biological diversity, water resources and forest transportation systems, and building consensus for adaptive strategies and actions.

- Conclusions Results suggest that this approach is an effective means for guiding management decisions to adapt to the effects of climate change, and provides an empirical basis for setting budgetary and management priorities.

Keywords Climate change vulnerability assessment . Adaptation prioritization

\section{Introduction}

Forest scientists, managers, and stakeholders are just beginning to fully comprehend the potential climate change effects on forest ecosystems and the goods and services they provide - water, wildlife, wood, biodiversity, and the mitigation of climate change itself. Forest managers and stakeholders are actively seeking advice and new decision support tools to adapt their management strategies to expected climate change, reduce the vulnerability of key natural and human systems to its effects, and ensure continued health and productivity of forest resources now and in the future. Forest scientists themselves are striving to understand the complex interactions of forest ecosystems and a changing climate, and extract from large-scale climate models practical information for operational planning and decision making. "Science-management partnerships" are emerging as a useful approach to facilitating this two-way communication and cooperation, and facilitating timely and effective action in response to climate change effects (Halofsky et al. 2011b; Peterson et al. 2011). 


\section{Policy direction for assessing and responding to climate change effects}

Intensive research on climate change over the past two decades has led most scientists to conclude that significant climate shifts and increased climate variability are already under way, and that this trend will continue for many centuries into the future (IPCC 2007). There is also general scientific consensus that the increasing concentration of greenhouse gasses in the atmosphere is accelerating these changes to a rate that has seldom if ever been experienced by natural or human systems (IPCC 2007). While research continues on ways to slow this process and mitigate climate change, it is clear that there is an urgent need for strategies for adaptation of natural and human systems in response to climate change effects to "moderate harm and exploit beneficial opportunities" (IPCC 2001).

This is a particular challenge for the management of forests. Most of forest science as we know it today was developed during the past two centuries, during a time of relative climate stability. Much of our understanding of the functioning of forest ecosystems and their response to disturbance or human intervention presumes a continuation of this relative stability. Prevailing strategies for conserving certain forest ecosystem values, such as native biological diversity, are also based upon this premise, assuming that animal and plant species will be protected by creating landscape preserves in their current geographic habitat range.

In forest management, it is widely assumed that successional patterns are stable over time, such that the effect of forest management activities can be predicted and directed with a high degree of confidence. What changes in climate might be taking place were slow in comparison with the typical rotation lengths of important tree species and other human uses of forest ecosystems (Peterson et al. 2011). The rate and magnitude of climate change that has already been experienced in temperate, boreal, and tropical forest ecosystems has already largely negated this concept of climate stability, and significantly diminished the ability to estimate future changes in these ecosystems (Milly et al. 2008).

In the USA, planning and management for adaptation to climate change in the conservation and sustainable management of forests are still in the very early stages. Federal land and resource management agencies in the USA have been slow to incorporate climate change into their existing processes for strategic and operational planning (GAO 2007, 2009). This is largely due to four factors:

- Insufficient local information on climate change effects

- The magnitude and uncertainty of potential effects on ecosystem structure, processes, and function

- The lack of institutional capacity_largely personnel and funding - to address a major new area of responsibility
- The absence of a policy mandate to incorporate climate change into the operations of federal land and resource management agencies (Peterson et al. 2011)

In 2008, the US Forest Service issued its Strategic Framework for Responding to Climate Change, which provided overall policy direction within the agency, but lacked guidance that forest managers needed to translate conceptual goals into tangible forest management and planning actions (US Forest Service 2008).

In 2010, this policy direction was followed by implementation guidelines for climate change adaptation actions (US Forest Service 2010). These guidelines were to be applied primarily on the 78 million hectares of National Forests directly managed by the agency, but they were also incorporated into the Forest Service's broader mission-as the leading forest management organization in the USA-for research, education, and technical assistance in support of sustainable forest management on state, tribal, private, and other nonfederal lands in the USA.

These implementation guidelines provided direction to local forest managers on how to (1) assess current risks, vulnerabilities, and gaps in knowledge, (2) engage internal agency resources and external partners in the development of options and solutions, and (3) manage forest resources for resilience, not just in terms of natural ecosystems but in affected human communities as well. Explicit consideration of climate change effects on local forest management activities is currently being incorporated into the federal regulations associated with the National Forest Management Act (16 U.S.C. 1600), one of the primary statutes that guide Forest Service programs and local-level planning.

\section{Development of a decision approach to guide forest management responses}

These new policy directives are intended to guide field-level forest managers in translating climate change concepts and goals into actions, but resource managers need information and tools that will enable them to make specific decisions, develop concrete practices, and take timely action on the ground to address current and expected climate change effects (Peterson et al. 2011).

In response to this need, the US Forest Service has brought its research stations and National Forests together in "science-management" partnerships "to develop scientific bases for adaptation and find effective ways to communicate and implement this knowledge" (Peterson et al. 2011). The science-management partnerships facilitate two-way learning. Field managers can communicate to scientists their observations about changing circumstances in their own locale. Scientists can then help extract and 
communicate the specific aspects of current climate science that can be melded with managers' field observations and their first-hand knowledge of the lands under their care. The decision approach typically followed by the science-management partnerships includes:

- Increasing awareness of basic climate change science and integrating that understanding with knowledge of local resource conditions and issues

- Evaluating the sensitivity of natural resources to climate change

- Developing and implementing options for adapting resources to climate change

- Monitoring the effectiveness of on-the-ground management and making midcourse adjustments as needed

The third step - developing and implementing a range of options - encompasses at least four alternative strategies to ensure sustainable resource management that continues to meet conservation goals (Peterson et al. 2011): (1) resistance, actions that enhance the ability of systems to resist the effects of climate change and maintain values and ecosystem services in desired conditions; (2) resilience, increased capacity of an ecosystem to withstand or absorb increasing effects without irreversible changes; (3) response, working directly with climate-induced changes to assist transitions to future states by minimizing undesired outcomes; and (4) realignment, using restoration to enable ecosystem functions to be sustained through changing climate

\section{Case study in Olympic National Forest/Olympic National Park}

The decision approach described above was used in a case study on the Olympic Peninsula, a heavily forested area of $6,300 \mathrm{~km}^{2}$ in northwestern Washington State, USA. Elevation on the peninsula ranges from sea level to $2,427 \mathrm{~m}$. The topography of the peninsula results in varied climatic conditions, from a wet, humid maritime climate on the west to a dry, continental climate east of the mountainous central portion of the peninsula. This case study was undertaken by the US Forest Service and the US National Park Service, which together manage most of the lands on the Olympic peninsula (Olympic National Park, and the surrounding Olympic National Forest), to develop: (1) an understanding of regionally applicable climate change science and potential impacts and (2) specific strategies and actions for climate change adaptation (Halofsky et al. 2011b). Natural resource specialists at Olympic National Forest and Olympic National Park chose to focus the study on: forest vegetation management, wildlife habitat management, fish habitat management, and hydrology and road system management. Hydrology and road system management was included as a focus area because the Forest Service and National Park Service manage more than $3,700 \mathrm{~km}$ of roads on the Olympic Peninsula. Most of these roads were built decades ago, primarily for logging purposes, using practices not consistent with today's standards. The high number of roads, heavy rainfall, steep slopes, frequent storm damage, and high recreational demand for well-maintained roads all lead to road maintenance being one of the major management activities on the peninsula, and one that affects both forest vegetation and habitat for fish and wildlife.

The process used for each focus area consisted of: (1) a literature review and assessment of the sensitivity of vegetation, fish, wildlife, and hydrology and roads to climate change; (2) a review of current management practices and constraints; and (3) development of adaptation plans of action through collaborative workshops, involving research scientists and resource specialists (e.g., botanists, geneticists, wildlife biologists, fisheries biologists, and hydrologists) from the Forest Service and National Park Service. Results of this process for each focus area are described below.

\subsection{Adapting forest vegetation management to climate change}

During a science-management workshop focused on adapting vegetation management to climate change, resource managers from Olympic National Forest and Olympic National Park identified four central goals for vegetation management on the Olympic peninsula (Halofsky et al. 2011a): maintain functioning ecosystems (not necessarily the same species or communities), maintain biodiversity, increase ecosystem resilience, and increase capacity to restore forest lands following large disturbance.

Based on an analysis of the vulnerability of the existing habitat types and their sensitivity to changing ecological processes (Halofsky et al. 2011a), four overarching priorities were identified by managers: (1) increase thinning (reduce competition in young growth, maximize tree growth and vigor, maximize tree species diversity and retention of minor tree species, and decrease forest density to increase drought resilience and promote shade intolerant species); (2) maintain seed inventory with high quality seed for a range of species; (3) develop gene conservation program for long-term storage of ex situ seed collections; and (4) identify areas for in situ gene conservation.

4.2 Adapting wildlife habitat management to climate change

The wildlife species assessment, involving a series of three science-management workshops, assisted in initially identifying species and groups of species that will likely be more sensitive to climate change on the peninsula (Halofsky et al. 2011c). The sensitivity assessment process indicated that 
specialist species and species that use sensitive habitats will likely be more sensitive to climate change than more generalist species and species that use less sensitive habitats. Two overarching priorities emerged from the analysis of projected sensitivities of wildlife species to climate change and potential adaptation strategies and actions (Halofsky et al. 2011c): (1) increase wildlife habitat resilience (planting native species that will respond favorably to climate change; protecting headwaters streams to increase connectivity and protect cold water flows; restoring degraded sites; and creating wetlands); and (2) intensive monitoring (prioritize monitoring of species most likely to be impacted by climate change; conduct surveys to obtain baseline information, locate potential migration corridors, and determine when population changes are occurring; survey post-fire regeneration for invasive species).

\subsection{Adapting fish habitat management to climate change}

The overall goal of fish habitat management at Olympic National Forest and Park is to maintain or restore diverse, resilient habitat capable of supporting native fish populations over the long term (Mantua et al. 2011). Recent habitat restoration efforts have typically attempted to maintain or recreate key watershed processes and functions, assuming that doing so would eventually recreate the historical river morphology and habitat conditions. Current restoration efforts are generally consistent with actions that will lead to increased ecosystem resilience under changing climate. However, increased restoration efforts and proactive management in priority areas will likely increase ecosystem resilience to climate change (Mantua et al. 2011).

In science-management workshops, managers identified specific management goals, including to: (1) recognize that existing channel conditions may not accurately represent future conditions, (2) monitor for early indications to determine how quickly climate-related changes are occurring, and (3) use this information to establish and adjust management priorities (Mantua et al. 2011). Initial priorities include: prevent the loss of headwaters habitat, restore habitat in degraded headwater streams that are expected to retain adequate summer stream flow, restore watershed processes and function and create diverse habitat, and control spread of exotic species, through monitoring and public education

\subsection{Adapting road system management to altered hydrology}

Across the western USA, increasing temperatures over the past 50 years have led to more precipitation falling as rain rather than snow, earlier snowmelt (Hamlet et al. 2007; Stewart et al. 2005), and reduced spring snowpack (Barnett et al. 2008; Hamlet et al. 2005; Mote 2003; Mote et al. 2005). Further reductions in snowpack and shifts in timing of snowmelt are expected with increasing temperatures in the twenty-first century. April 1 snow water equivalent (a measure of water in snowpack) is projected to decrease by an average of $27-29 \%$ across Washington state by the 2020 s, 37-44 \% by the 2040 s, and $53-65 \%$ by the 2080 s (Elsner et al. 2010).

Changes in snowpack are particularly important for the mountainous regions of the western USA, including the Pacific Northwest, because snowmelt provides approximately $70 \%$ of annual stream flow in these regions (Mote et al. 2008). Warming temperatures affect the timing of snowmelt and associated seasonal stream flow. Both increased winter rain (as opposed to snow) and shifts to earlier spring snowmelt result in higher winter and spring stream flows and lower summer stream flows in snowmeltdominated and transient (rain/snow mixed) watersheds (Elsner et al. 2010; Stewart et al. 2005).

Projected hydrologic effects of climate change will likely affect physical watershed processes. Increased precipitation and storm intensity, higher snowlines, and loss of snow cover are expected to lead to increased rate and volume of water delivery to channels, increased mass wasting and debris flows, and increased sediment and wood delivery to streams (Benda and Dunne 1997).

Road management is a major activity at both Olympic National Forest and Olympic National Park. Assessing current road maintenance and operations tasks in the context of climate change can inform managers of necessary changes. Anticipating the effects from changes in watershed processes also informs the design of roads and related structures. The goal of road management at Olympic National Forest and Park is to provide a safe and economical transportation system to meet the access needs of various users while minimizing potential adverse impacts to other resources.

Key adaptive actions identified in this study are: (1) prioritize road system risks, recognizing that roads adjacent to streams are most vulnerable to damage, and (2) consider whether road relocation is the best option in terms of future expense (Halofsky et al. 2011d). Site-specific analysis is needed to evaluate the density, location, design, and maintenance intensity of roads and related structures in the context of climate change to avoid escalating road maintenance costs associated with climate-related impacts. Roads in valley bottoms are particularly susceptible to flood damage, and moving these roads to other locations, when possible, may be desirable. Roads within or downslope of transient snow zones or snow-dominated areas will likely be subjected to increased flood damaged because of more precipitation in the form of rain and increased storm intensity. These roads may require more intense treatments or more frequent maintenance. Increased flexibility in forest road management policies will allow management actions to shift more rapidly in response to new information on climatic changes and ecosystem response (Halofsky et al. 2011d). 


\section{Conclusions}

The decision approach described here produced specific and tangible ways for Olympic National Forest and Olympic National Park to incorporate climate change adaptation strategies into management. Direct engagement of scientists and managers in workshops facilitated development of science-based adaptation strategies. The success of the process required strong commitments by all parties, individuals dedicated to facilitating the process, focused time from staff specialists, sufficient time to establish a common foundation of information among participants, bracketing of discussions by focus area to increase specificity of adaptation tactics, and synthesis across focus areas.

The workshop series was useful to begin the conversation on how climate change may influence land management and to identify adaptation actions, but future work is necessary to refine ideas, implement them on the ground, and monitor their effectiveness over time. Initial discussions in group settings are often general to explore varied perspectives and solicit ideas. In future efforts, additional structure may help in the development of more specific adaptation options. Balancing between soliciting input from many people in workshops and having a group that is sufficiently small to enable discussion was a challenge in this effort. A desirable next step is to include other partners in a broader climate change adaptation discussions on the peninsula. Future iterations of a process such as the one used in this study will also likely lead to better-informed adaptation actions by natural resource agencies.

US forest scientists, managers, and stakeholders are moving forward on many fronts to improve scientific understanding of climate change effects on forest ecosystems, and to develop information on how forest management activities can reduce the vulnerability of natural and human systems to actual or expected climate change effects. Clear policy directives have helped establish climate change adaptation as a priority within the US Forest Service as the leading forestry organization in the USA, not just in the management of federal forest lands, but in research, education, and technical assistance in support of the conservation and sustainable management of all forest lands across the nation.

Major challenges lie ahead in understanding and anticipating the diverse effects of climate change on the temperate, boreal, and subtropical forest ecosystems represented in the USA. Even greater challenges may confront forest managers who are striving to protect the health and productivity of forest resources for a multitude of goods, services, and values. Given the difficulties that many scientists anticipate in maintaining abundant supplies of clean water for municipal, agricultural, and industrial uses, it will be especially critical to anticipate and address climate change effects on forest watersheds and their role in water resource protection. Conserving native biodiversity will also be a major challenge, now that it is clear that the prevailing strategy of in situ protection through designation of preserves and other protected areas is likely to be inadequate as species begin to migrate in response to climate change.

The continuing engagement and cooperation of scientists, resource managers, and stakeholders in "science-management partnerships" will play an essential role, enabling forest managers and stakeholders to communicate an evolving set of needs and opportunities, and allowing scientists to communicate immediately useful information that facilitates the development of practical solutions that reduce the vulnerability of natural and human systems to the effects of climate change.

Acknowledgments The authors wish to thank Marc R. Magaud of the Embassy of France in the USA, Office of Environment and Sustainable Development, Washington, DC, and Jean-Luc Peyron of GIPECOFOR, Paris, for their assistance and support. Major funding for this research was provided by the U.S. Forest Service, Office of Research and Development, Pacific Northwest Research Station.

\section{References}

Barnett T, Pierce D, Hidalgo H (2008) Human-induced changes in the hydrology of the western United States. Science 19:1080-1083

Benda L, Dunne T (1997) Stochastic forcing of sediment supply to channel networks from landsliding and debris flow. Water Resour Res 33:2849-2863

Elsner M, Cuo L, Voisin N (2010) Implications of 21st century climate change for the hydrology of Washington State. Clim Chang 102:225-260

GAO (2007) Climate change: agencies should develop guidance for addressing the effects on federal land and water resources. GAO07-863. US General Accountability Office, Washington, DC

GAO (2009) Climate change adaptation: strategic federal planning could help government officials make more informed decisions. GAO-10-113. US General Accountability Office, Washington, DC

Halofsky JE, Peterson DL, Aubry C, Dowling C, Acker SA (2011a) Climate change and vegetation management at Olympic National Forest and Olympic National Park. In: Halofsky J, Peterson D, O'Halloran K, Hoffman C (eds) Adapting to climate change at Olympic National Forest and Olympic National Park. General technical report PNW-GTR-844. US Forest Service, Portland

Halofsky J, Peterson D, O'Halloran K, Hoffman C (eds) (2011b) Adapting to climate change at Olympic National Forest and Olympic National Park. General technical report PNW-GTR844. US Forest Service, Portland, OR

Halofsky JE, Piper S, Aluzas K, Howell B, Griffin P, Happe P, Jenkins K, Hawkins Hoffman C, Lawler J, Case M, Reagan $\mathrm{K}$ (2011c) Climate change, wildlife management, and habitat management at Olympic National Forest and Olympic National Park. In: Halofsky J, Peterson D, O’Halloran K, Hoffman C (eds) Adapting to climate change at Olympic National Forest and Olympic National Park. General technical report PNW-GTR-844. US Forest Service, Portland 
Halofsky JE, Shelmerdine WS, Stoddard R, Metzger R, Hamlet RF, Hawkins Hoffman C (2011d) Climate change, hydrology, and road management at Olympic National Forest and Olympic National Park. In: Halofsky J, Peterson D, O’Halloran K, Hoffman C (eds) Adapting to climate change at Olympic National Forest and Olympic National Park. General technical report PNW-GTR-844. US Forest Service, Portland

Hamlet A, Mote P, Clark M, Lettenmaier D (2005) Effects of temperature and precipitation variability on snowpack trends in the Western US. J Clim 18:4545-4561

Hamlet A, Mote P, Clark M, Lettenmaier D (2007) 20th Century trends in runoff, evapotranspiration, and soil moisture in the Western US. J Clim 20:1468-1486

IPCC (2001) Climate change 2001: third assessment report of the Intergovernmental Panel on Climate Change. Cambridge University Press, Cambridge

IPCC (2007) In: Pachauri RK, Reisinger A (eds) Climate change 2007: synthesis report; a contribution of working groups I, II and III to the fourth assessment report of the Intergovernmental Panel on Climate Change. IPCC, Geneva, $104 \mathrm{p}$

Mantua NJ, Metzger R, Crain P, Brenkman S, Halofsky JE (2011) Climate change, fish, and fish habitat management at Olympic National Forest and Olympic National Park. In: Halofsky J, Peterson D, O'Halloran K, Hoffman C (eds) Adapting to climate change at Olympic National Forest and Olympic National Park.
General technical report PNW-GTR-844. US Forest Service, Portland

Milly P, Betancourt J, Falkenmark M, Hirsh R, Kundzewicz Z, Lettenmaier D, Stouffer R (2008) Stationarity is dead: whither water management? Science 319:572-574

Mote P (2003) Trends in snow water equivalent in the Pacific Northwest and their climatic gauses. Geophys Res Lett 30:1601

Mote P, Hamlet A, Clark M, Lettenmaier D (2005) Declining mountain Snowpak in Western North American. Bull Am Meteorol Soc 86:39-49

Mote PW, Hamlet AF, Salathe EP (2008) Has spring snowpack declined in the Washington Cascades? Hydrology and Earth System Sciences. 12:193-206

Peterson D, Millar C, Joyce L, Furniss M, Halofsky J, Neilson R, Morelli $\mathrm{T}$ (2011) Responding to climate change in National Forests: a guidebook for developing adaptation options. General technical report PNW-GTR-855. US Forest Service, Portland, Oregon

Stewart I, Cayan D, Dettinger M (2005) Changes towards earlier streamflow timing across Western North America. J Climatol 18:1136-1155

US Forest Service (2008) Forest Service strategic framework for responding to climate change. www.fs.fed.us/climatechange/ documents/strategic-framework-climate-change-1-0.pdf

US Forest Service (2010) National roadmap for responding to climate change. www.fs.fed.us/climatechange/pdf/roadmap.pdf 